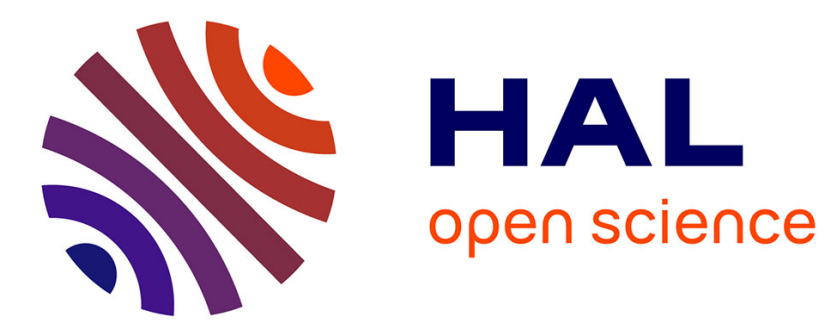

\title{
Paleomagnetic study of French Guyana Early Jurassic dolerites: hypothesis of a multistage magmatic event
}

Sébastien Nomade, Hervé Théveniaut, Yan Chen, André Pouclet, Christophe Rigollet

\section{- To cite this version:}

Sébastien Nomade, Hervé Théveniaut, Yan Chen, André Pouclet, Christophe Rigollet. Paleomagnetic study of French Guyana Early Jurassic dolerites: hypothesis of a multistage magmatic event. Earth and Planetary Science Letters, 2000, 184, pp.155-168. 10.1016/S0012-821X(00)00305-8 . hal00115153

\section{HAL Id: hal-00115153 \\ https://hal-insu.archives-ouvertes.fr/hal-00115153}

Submitted on 26 Mar 2021

HAL is a multi-disciplinary open access archive for the deposit and dissemination of scientific research documents, whether they are published or not. The documents may come from teaching and research institutions in France or abroad, or from public or private research centers.
L'archive ouverte pluridisciplinaire HAL, est destinée au dépôt et à la diffusion de documents scientifiques de niveau recherche, publiés ou non, émanant des établissements d'enseignement et de recherche français ou étrangers, des laboratoires publics ou privés. 


\title{
Paleomagnetic study of French Guyana Early Jurassic dolerites: hypothesis of a multistage magmatic event
}

\author{
S. Nomade ${ }^{\mathrm{a}, *}, \mathrm{H}$. Théveniaut ${ }^{\mathrm{b}}, \mathrm{Y}$. Chen ${ }^{\mathrm{a}}$, A. Pouclet ${ }^{\mathrm{a}}$, C. Rigollet ${ }^{\mathrm{a}}$ \\ a Département des Sciences de la Terre, UMR 6530, ISTO, Université d'Orléans, 45067 Orléans Cedex 2, France \\ b BRGM, SGN, 3, avenue Claude Guillemin, P.O. Box 6009, 45060 Orléans Cedex 2, France
}

2000

\begin{abstract}
A detailed paleomagnetic and anisotropy of magnetic susceptibility (AMS) study was carried out on 34 sites of Early Jurassic dolerite dykes from French Guyana, which formed during the initial opening of the Central Atlantic Ocean. Four types of AMS fabrics are recognized: (i) 'Normal' fabric (21 dykes) defined by clustering of $K_{1}-K_{2}$ axes on the dyke plane whereas the $\mathrm{K}_{3}$ axis is nearly perpendicular to it. This fabric is interpreted as due to magma flow. The subhorizontal inclination of the $K_{1}$ axis permitted to suggest that the French Guyana dykes could be fed by horizontal magma fluxes from a distant magma source. (ii) 'Reversal' fabric ( 8 dykes) is characterized by the $K_{2}-K_{3}$ plane close to the dyke plane and the $K_{1}$ perpendicular to dyke orientation. Such fabric was attributed to the local shearing stress. (iii) 'Intermediate' fabric ( 1 dyke) is defined by $K_{1}-K_{3}$ axes close to the dyke plane and $K_{2}$ axis is perpendicular to this plane. It was interpreted as due to vertical compaction of a static magma column. (iiii) 'Other' fabric (4 dykes) does not show any preferential orientation. Scanning electronic microscope and susceptibility versus temperature experiments show that minerals of the titanomagnetite family are main magnetic remanence carriers. Two magnetic components were isolated. Ages of magnetic remanences are estimated at $198.3 \pm 2.0 \mathrm{Ma}$ to $192.3 \pm 1.5 \mathrm{Ma}$. Their virtual geomagnetic poles are calculated, Pole A: $\lambda=73.2^{\circ} \mathrm{N}, \phi=15.3^{\circ} \mathrm{E}, k=288.8, A_{95}=3.4^{\circ}, n=8$, and Pole B: $\lambda=81.6^{\circ} \mathrm{N}, \phi=89.1^{\circ} \mathrm{E}$, $k=69.8, A_{95}=4.2^{\circ}, n=18$. These two groups probably correspond to two distinct magmatic events which occurred in a short period. This hypothesis is consistent with published ${ }^{40} \mathrm{Ar}-{ }^{39} \mathrm{Ar}$ radiometric ages though with 'mini plateau' spectra. These paleomagnetic results suggest the presence of magmatic pulses led to the construction of the Central Atlantic Magmatic Province in French Guyana during the Early Jurassic. (C) 2000 Elsevier Science B.V. All rights reserved.
\end{abstract}

Keywords: paleomagnetism; anisotropy; magnetic susceptibility; French Guiana; diabase; magmatism

\section{Introduction}

Extensive dyke swarms cut both Paleoprotero- zoic basement rocks of the Guyana shield and sedimentary rocks of the Amazonian basin. They are mostly present along the coastal margins, however inland large basaltic floods associated with the dykes are also widespread. These swarms, such as the Cassipore and Cayenne swarms in Amapa (Brazil) and French Guyana are dominantly NNW-SSE-oriented, nearly paral- 
lel to the rifting direction of the Central Atlantic Ocean [1] (Fig. 1). Similar dyking events have been recognized around the Central Atlantic Ocean, from the European and North American continental margins, to the West African and South American coasts, thus constituting the largest volcanic province in the world: the Central Atlantic Magmatic Province (CAMP) [2]. ${ }^{40} \mathrm{Ar}-$ ${ }^{39} \mathrm{Ar}$ and ${ }^{238} \mathrm{U}-{ }^{206} \mathrm{~Pb}$ ages [2,3] of the CAMP basaltic magmatism cluster around $200 \mathrm{Ma}$, close to the Triassic-Jurassic boundary. If this magmatic event is commonly associated with the initiation of continental rifting as suggested by several workers $[4,5]$, the migration of magma from partial melting zones in the mantle towards the surface is poorly understood. The magma could be injected directly from the mantle source [6] or laterally injected from shallow magma chambers fed by vertical conduits connected to the mantle [7]. The understanding of timing, emplacement, tectonic control and identified magma sources could allow to answer these questions. In particular, the anisotropy of magnetic susceptibility technique (AMS) offers a powerful tool to inves-

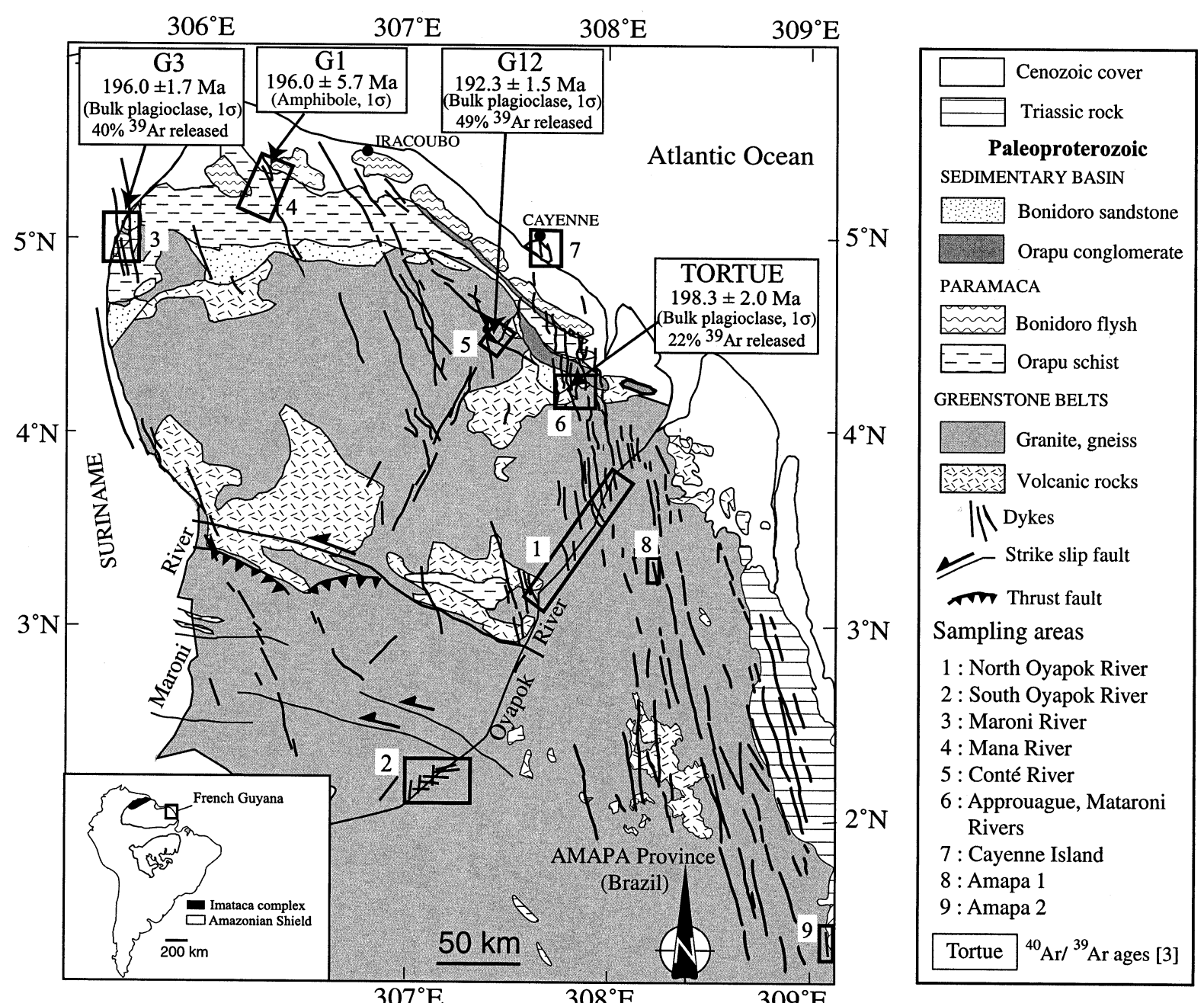

Fig. 1. Simplified geological map of French Guyana showing the South American Amazonian Shield, location of the sampling areas and recently dated dykes [3]. 
tigate flow directions, proxy flow indicator, or stress direction [8-10]. Moreover, coupling radiochronological ages with paleomagnetic results should better constrain the predrift magmatic process and timing of dyke emplacement. Up to now, no AMS study has been carried out on Early Jurassic dykes in South America. Until recently, paleomagnetic data concerning Early Jurassic dolerites of the Amazonian Shield were not satisfactory enough as they were scarce and only supported by ${ }^{40} \mathrm{~K}-{ }^{40} \mathrm{Ar}$ dating [11-14]. Recent geochronological ${ }^{40} \mathrm{Ar}-{ }^{39} \mathrm{Ar}$ results on the basaltic dykes from French Guyana [3] are also helpful for the understanding of the magmatism of the CAMP in French Guyana.

In the framework of a multidisciplinary BRGM (French Geological Survey) geological mapping project of the French Guyana Territory in collaboration with ISTO and the CPRM (Geological Survey of Brazil), we carried out four field trips between 1995 and 1998. We collected samples from all representative formations and a particular care was taken on dykes, some being recently dated $[3,15]$. Indeed, a better understanding of dyke emplacement in age and space should better constrain the predrift fracturation process which affected French Guyana during Early Jurassic.

\section{Geological setting and paleomagnetic sampling}

\subsection{Geological setting}

The Guyana Shield, which underlies French Guyana is mainly composed of granite-greenstone belts ranging in age from 2.2 to $2.0 \mathrm{Ga}$ due to the Transamazonian tectonothermal event [16] (Fig. 1), with evidence of Archean basement on its western margin (Imataca Complex, Venezuela, [17]). In French Guyana, the basement mainly consists of plutonic rocks and greenstone belts forming two large zones intruded by large granitic complexes [18] (Fig. 1). The northern part of Guyana is occupied by an EW-elongated Paleoproterozoic sedimentary basin filled by the Orapu conglomerate and the Bonidoro sandstone Formations [18,19] (Fig. 1).

Two principal doleritic magmatic events have

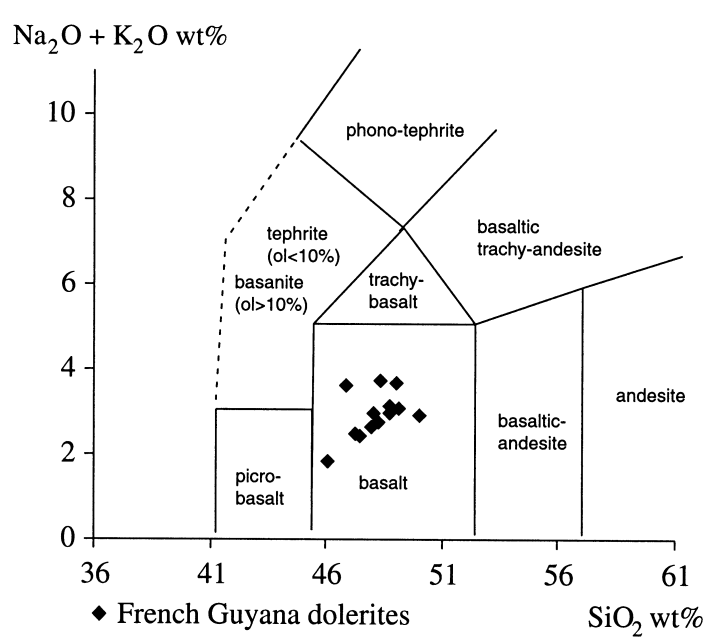

Fig. 2. Total alkalis versus silica diagram (T.A.S) [20].

affected the Guyana Shield: the Paleoproterozoic Avanavero Intrusive Group and the Early Jurassic Apatao Group [11]. In French Guyana the majority of the dyke-swarms are NNW-SSEtrending Early Jurassic basalt [3] (Fig. 1). All investigated rocks have basaltic (sensu lato) compositions [20] (Fig. 2) with intergranulare, ophitic, (sub)ophitic or gabbroic textures. The (sub)ophitic texture is observed in the majority of dykes. The mineralogy consists of olivine $\left(\mathrm{Fo}_{40}-\right.$ $\left.\mathrm{Fo}_{70}\right)$, plagioclase $\left(\mathrm{An}_{40}-\mathrm{An}_{60}\right)$ and augite. The groundmass is composed of fine-grained plagioclase, augite \pm pigeonite, skeleton-like $\mathrm{Fe}-\mathrm{Ti}$ oxides, and, possibly biotite and/or hornblende. French Guyana dolerites are characterized by a lack of LILE enrichment ( $\mathrm{Ba}, \mathrm{Rb}, \mathrm{Th})$, primitive mantle normalized $(\mathrm{La} / \mathrm{Yb}) \mathrm{n}$ ratios ranging from 1.8 to 4.6 , and high $\mathrm{TiO}_{2}(<2 \%)$. They likely correspond to a mixed MORB-EMII mantle source [15].

\subsection{Paleomagnetic sampling}

In French Guyana, Jurassic dykes are numerous, well exposed, and cut vertically through $\mathrm{Pa}-$ leoproterozoic rocks. Their width varies from 1 to $30 \mathrm{~m}$ but generally does not exceed 3-5 m. Samples were collected from 32 sites along the Oyapok, Maroni, Mana, Conté, Approuague and Mataroni rivers, and on the Cayenne Island 

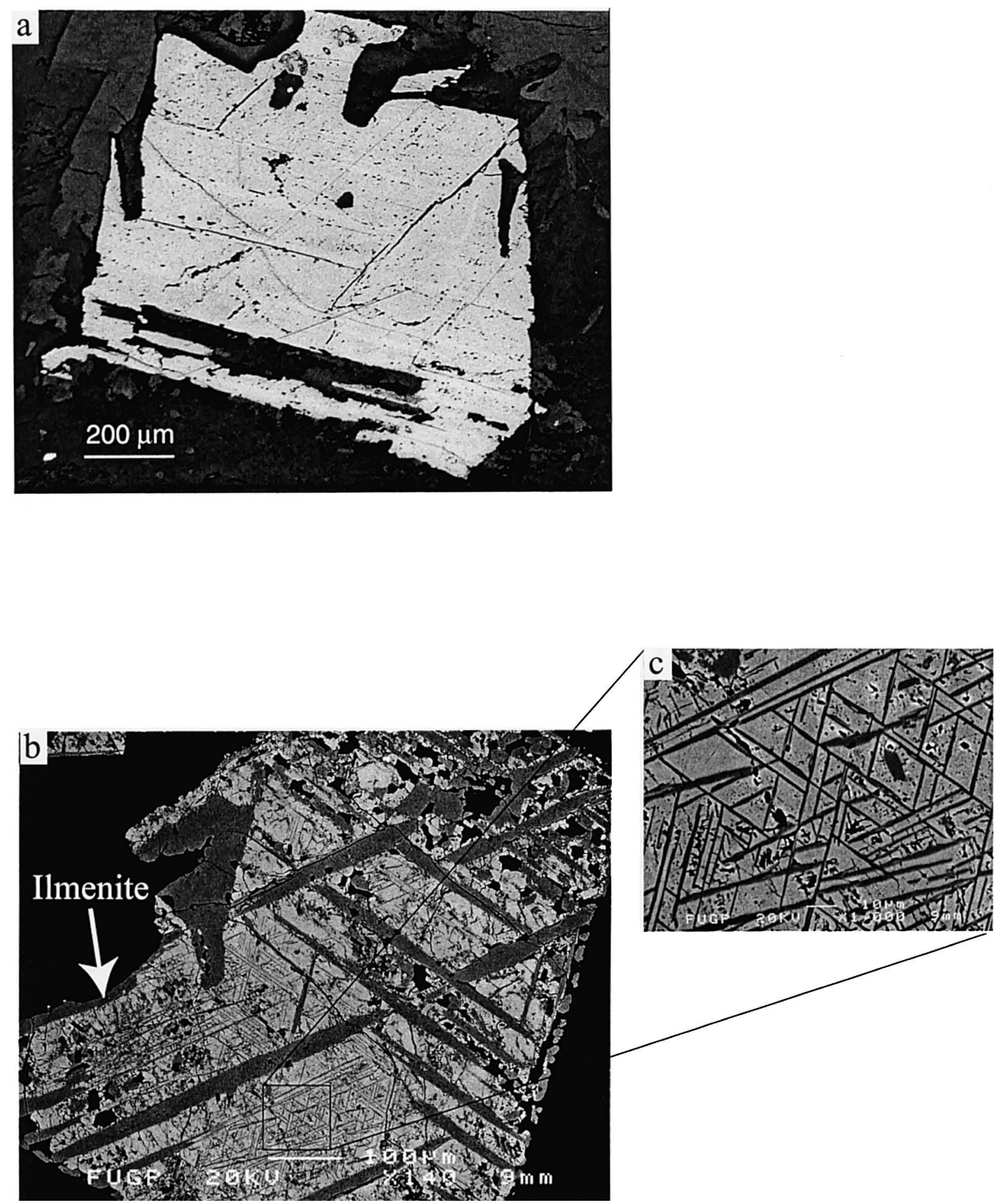

Fig. 3. (a) Reflected light photo of a large automorphous titanomagnetite grain. (b) Large-scale image in secondary electrons of titanomagnetite with the complex structure of ilmenite exsolution. (c) Close scale image in secondary electrons of fractal disposition of ilmenite exsolution in titanomagnetite. 
(Fig. 1). Two dykes were also sampled in Amapa (Fig. 1). Four sites were recently dated by the ${ }^{40} \mathrm{Ar}-{ }^{39} \mathrm{Ar}$ method [3,15] (Fig. 1). Dyke azimuths vary from N330 to N020 and were measured in 21 dyke walls. The other azimuths (13 dykes) were interpreted from the geophysical data. In all well exposed dykes (21), a fine congealed margin $(<2 \mathrm{~cm})$ was observed. Six to eight 2.54 $\mathrm{cm}$ in diameter cylinders crossing through the dyke in width were drilled perpendicular to the strike of the dyke at each site. Cores were orientated with magnetic and, whenever possible, with sun compass. The difference between solar and magnetic azimuth measurements is about $20 \pm 4^{\circ}$, which is compatible with the 1998 IGRF declination $\left(17.5^{\circ}\right)$. Samples were also taken for mineralogical and chemical analyses. Cores were cut to standard size $(2.54 / 2.2 \mathrm{~cm})$, yielding 260 specimens.

\section{Laboratory measurements}

\subsection{Petrographic and magnetic mineralogical analyses}

In order to characterize the magnetic mineralogical compositions of our collection, we applied the following methods on representative samples: reflection microscopy (Olympus BX60) at the geological laboratory of the Université d'Orléans;

Table 1

Titanomagnetite microprobe analyses showing a variable concentration of titanium oxides

\begin{tabular}{lllll}
\hline & GR2 & FU8 & GW1 & HA6 \\
\hline $\mathrm{SiO}_{2}$ & 0.05 & 0.10 & 0.11 & 0.17 \\
$\mathrm{TiO}_{2}$ & 4.80 & 8.23 & 19.44 & 11.23 \\
$\mathrm{Al}_{2} \mathrm{O}_{3}$ & 2.96 & 1.18 & 2.26 & 1.93 \\
$\mathrm{Cr}_{2} \mathrm{O}_{3}$ & 0.00 & 0.26 & 0.20 & 0.10 \\
$\mathrm{~V}_{2} \mathrm{O}_{3}$ & 0.96 & 3.42 & 1.07 & 0.64 \\
$\mathrm{FeO}$ & 86.42 & 79.88 & 73.56 & 77.71 \\
$\mathrm{FeO}$ & 36.21 & 38.23 & 48.71 & 40.61 \\
$\mathrm{Fe}_{2} \mathrm{O}_{3}$ & 55.84 & 46.31 & 27.64 & 41.26 \\
$\mathrm{MnO}$ & 0.11 & 0.21 & 0.49 & 0.20 \\
$\mathrm{MgO}$ & 0.05 & 0.01 & 0.36 & 0.03 \\
$\mathrm{ZnO}$ & 0.00 & 0.00 & 0.00 & 0.00 \\
$\mathrm{Total} \mathrm{Fe} 0 *$ & 95.35 & 93.29 & 97.48 & 92.00 \\
Total & 100.98 & 97.95 & 100.27 & 96.16 \\
\hline
\end{tabular}
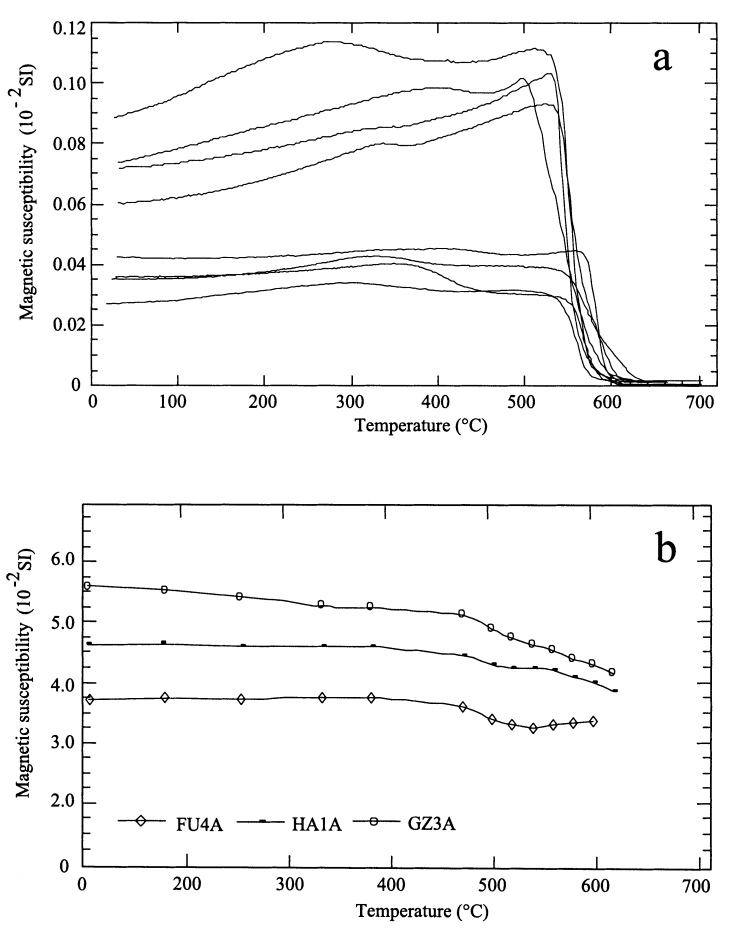

Fig. 4. (a) Magnetic susceptibility variation versus temperature for some dykes of French Guyana showing a susceptibility drop between 550 and $575^{\circ} \mathrm{C}$. (b) Bulk susceptibility variation during thermal demagnetization from selected samples (dykes FU4A, HA1A and GZ3A).

electronic scanning microscopy (JEOL instrument) at Ecole Supérieure de l'Energie et des Matériaux (ESEM), and thermomagnetic experiments using a CS3 apparatus (AGICO, Geofysica) coupled with a KLY-3S kappabridge (AGICO, Geofysica) at the joint BRGM/Université d'Orléans Laboratoire de Magnétisme des Roches (LMR).

Petrographic observations with reflected light microscopy show large automorphous grains of titanomagnetite (Fig. 3a). Scanning electron microscopy (SEM) observations present more detailed information on the structure of the large titanomagnetite grains. Fig. 3b,c show two secondary electrons images of a $0.5 \mathrm{~mm}$ titanomagnetite grain at two scales. A complex fractal structure of ilmenite lamella exsolutions has been observed in the titanomagnetite crystal body (Fig. 3c). This kind of structure is well known in basaltic rocks and results from the exsolution 
of ilmenite during magmatic cooling between 550 and $515^{\circ} \mathrm{C}$ [21]. No later destabilization was observed in titanomagnetite. The microprobe analyses on titanomagnetite are listed in Table 1. Titanium oxide concentration ranges from 4 to 20 percent. Thermomagnetic experiments confirm that titanomagnetite is the main magnetic carrier (Fig. 4a). Indeed, Fig. 4a shows a sharp drop of the low field magnetic susceptibility between 550 and $575^{\circ} \mathrm{C}$. Bulk susceptibility measurements made after each heating step show only minor variations which indicate that the magnetic mineralogical transformations during heating are insignificant (Fig. 4b).

In short, petrographic and magnetic mineralogical analyses indicate that the remanent magnetization in the dolerites is carried solely by minerals of the titanomagnetite family.

Table 2

AMS data

\begin{tabular}{|c|c|c|c|c|c|c|c|c|c|c|c|c|c|c|c|c|c|}
\hline \multirow[t]{2}{*}{ Sites } & \multirow[t]{2}{*}{$F$} & \multirow[t]{2}{*}{$L$} & \multirow[t]{2}{*}{$P$} & \multirow[t]{2}{*}{$T$} & \multicolumn{4}{|c|}{$K_{1}$} & \multicolumn{4}{|c|}{$K_{2}$} & \multicolumn{4}{|c|}{$K_{3}$} & \multirow{2}{*}{$\begin{array}{l}\text { Fabric } \\
\text { type }\end{array}$} \\
\hline & & & & & $D$ & $I$ & $\begin{array}{l}\alpha_{95 \min } \\
\left(^{\circ}\right)\end{array}$ & $\begin{array}{l}\alpha_{95 \max } \\
\left(^{\circ}\right)\end{array}$ & $D$ & $I$ & $\begin{array}{l}\alpha_{95 \min } \\
\left(^{\circ}\right)\end{array}$ & $\begin{array}{l}\alpha_{95 \max } \\
\left(^{\circ}\right)\end{array}$ & $D$ & $I$ & $\begin{array}{l}\alpha_{95 \min } \\
\left(^{\circ}\right)\end{array}$ & $\begin{array}{l}\alpha_{95 \max } \\
\left(^{\circ}\right)\end{array}$ & \\
\hline FU & 1.010 & 1.007 & 1.017 & 0.152 & 211 & 13 & 6 & 8 & 281 & 36 & 10 & 11 & 105 & 53 & 7 & 10 & $\mathrm{R}$ \\
\hline GR & 1.010 & 1.019 & 1.029 & -0.301 & 38 & 1 & 5 & 6 & 300 & 79 & 7 & 24 & 128 & 11 & 3 & 24 & $\mathrm{R}$ \\
\hline GT & 1.005 & 1.013 & 1.018 & -0.488 & 220 & 33 & 8 & 12 & 341 & 39 & 9 & 30 & 104 & 34 & 7 & 28 & $\mathrm{R}$ \\
\hline GU & 1.023 & 1.017 & 1.040 & 0.141 & 175 & 7 & 6 & 8 & 68 & 67 & 5 & 9 & 267 & 22 & 5 & 7 & $\mathrm{~N}$ \\
\hline GV & 1.065 & 1.017 & 1.082 & 0.577 & 186 & 3 & 3 & 9 & 283 & 67 & 1 & 9 & 95 & 22 & 3 & 4 & $\mathrm{~N}$ \\
\hline GW & 1.032 & 1.008 & 1.040 & 0.610 & 267 & 68 & 9 & 40 & 19 & 8 & 14 & 40 & 112 & 20 & 8 & 13 & $\mathrm{~N}$ \\
\hline GZ & 1.019 & 1.013 & 1.032 & 0.188 & 199 & 0 & 4 & 7 & 108 & 54 & 4 & 7 & 289 & 36 & 5 & 6 & $\mathrm{R}$ \\
\hline HA & 1.005 & 1.005 & 1.011 & 0.100 & 190 & 20 & 12 & 14 & 303 & 41 & 11 & 13 & 81 & 51 & 7 & 15 & $\mathrm{~N}$ \\
\hline $\mathrm{O} 1$ & 1.011 & 1.008 & 1.019 & 0.163 & 340 & 1 & 3 & 5 & 239 & 82 & 5 & 6 & 70 & 8 & 4 & 6 & $\mathrm{~N}$ \\
\hline $\mathrm{O} 3$ & 1.006 & 1.014 & 1.020 & -0.421 & & & & & & & & & & & & & $\mathrm{~N}$ \\
\hline $\mathrm{O} 4$ & 1.004 & 1.014 & 1.018 & -0.542 & 52 & 61 & 11 & 13 & 213 & 24 & 8 & 27 & 320 & 8 & 7 & 28 & $\mathrm{~N}$ \\
\hline O5 & 1.023 & 1.011 & 1.034 & 0.366 & 337 & 24 & 5 & 13 & 240 & 16 & 6 & 8 & 120 & 60 & 4 & 7 & $\mathrm{~N}$ \\
\hline O7 & 1.047 & 1.016 & 1.063 & 0.482 & 157 & 18 & 5 & 13 & 256 & 25 & 5 & 13 & 49 & 54 & 3 & 6 & I \\
\hline O9 & 1.031 & 1.013 & 1.045 & 0.403 & 168 & 2 & 1 & 14 & 263 & 38 & 2 & 4 & 189 & 60 & 1 & 13 & $\mathrm{~N}$ \\
\hline 10 & 1.021 & 1.014 & 1.036 & 0.239 & 334 & 23 & 9 & 10 & 198 & 59 & 3 & 12 & 70 & 20 & 6 & 9 & $\mathrm{~N}$ \\
\hline 15 & 1.011 & 1.012 & 1.023 & -0.047 & 252 & 21 & 6 & 8 & 30 & 62 & 13 & 28 & 353 & 15 & 5 & 13 & $\mathrm{R}$ \\
\hline 17 & 1.038 & 1.018 & 1.057 & 0.345 & 154 & 1 & 5 & 9 & 251 & 80 & 4 & 28 & 64 & 10 & 5 & 7 & $\mathrm{~N}$ \\
\hline 23 & 1.037 & 1.011 & 1.049 & 0.549 & 345 & 13 & 7 & 10 & 137 & 76 & 2 & 8 & 254 & 7 & 2 & 9 & $\mathrm{~N}$ \\
\hline PD & 1.039 & 1.002 & 1.041 & 0.924 & 157 & 2 & 5 & 13 & 249 & 40 & 4 & 13 & 64 & 49 & 3 & 5 & $\mathrm{~N}$ \\
\hline PI & 1.055 & 1.013 & 1.068 & 0.601 & 351 & 12 & 4 & 13 & 183 & 78 & 4 & 13 & 82 & 2 & 3 & 6 & $\mathrm{~N}$ \\
\hline $\mathrm{OU}$ & 1.005 & 1.005 & 1.009 & 0.012 & & & & & & & & & & & & & $\mathrm{O}$ \\
\hline GosD1 & 1.011 & 1.014 & 1.025 & 0.100 & 252 & 13 & 4 & 7 & 345 & 11 & 6 & 11 & 115 & 73 & 4 & 6 & $\mathrm{R}$ \\
\hline BouD6 & 1.020 & 1.011 & 1.032 & -0.295 & 46 & 1 & 4 & 13 & 136 & 1 & 8 & 18 & 275 & 88 & 4 & 6 & $\mathrm{R}$ \\
\hline CY & 1.003 & 1.015 & 1.018 & 0.667 & 184 & 14 & 6 & 19 & 73 & 53 & 5 & 19 & 316 & 55 & 3 & 12 & $\mathrm{~N}$ \\
\hline CQ & 1.011 & 1.038 & 1.049 & 0.560 & 187 & 21 & 4 & 25 & 289 & 29 & 14 & 26 & 66 & 53 & 2 & 15 & $\mathrm{~N}$ \\
\hline PolD4 & 1.018 & 1.007 & 1.024 & -0.376 & 44 & 17 & 4 & 33 & 309 & 14 & 9 & 14 & 171 & 72 & 12 & 13 & $\mathrm{R}$ \\
\hline polD5 & 1.004 & 1.010 & 1.015 & 0.401 & & & & & & & & & & & & & $\mathrm{O}$ \\
\hline $\mathrm{AN}$ & 1.010 & 1.020 & 1.030 & 0.292 & 145 & 12 & 6 & 15 & 240 & 57 & 8 & 19 & 59 & 18 & 7 & 12 & $\mathrm{~N}$ \\
\hline AQ & 1.008 & 1.043 & 1.051 & 0.683 & 159 & 60 & 1 & 23 & 9 & 31 & 4 & 23 & 259 & 16 & 3 & 4 & $\mathrm{~N}$ \\
\hline $\mathrm{BN}$ & 1.035 & 1.027 & 1.064 & -0.123 & 136 & 17 & 4 & 16 & 295 & 71 & 4 & 16 & 232 & 7 & 4 & 17 & $\mathrm{~N}$ \\
\hline BO & 1.019 & 1.018 & 1.037 & -0.050 & 348 & 0 & 7 & 19 & 253 & 84 & 14 & 22 & 78 & 6 & 9 & 18 & $\mathrm{~N}$ \\
\hline $\mathrm{BP}$ & 1.028 & 1.053 & 1.085 & 0.186 & 159 & 3 & 3 & 17 & 253 & 39 & 10 & 37 & 80 & 50 & 6 & 30 & $\mathrm{~N}$ \\
\hline BQ & 1.004 & 1.007 & 1.011 & 0.297 & & & & & & & & & & & & & $\mathrm{O}$ \\
\hline BR & 1.003 & 1.036 & 1.039 & 0.859 & 158 & 5 & 12 & 24 & 60 & 57 & 8 & 25 & 252 & 33 & 10 & 14 & $\mathrm{~N}$ \\
\hline
\end{tabular}

$K_{1}, K_{2}$ and $K_{3}$ are the maximum, intermediate and minimum susceptibility intensities; $F$, mean foliation $\left(K_{2} / K_{3}\right) ; L$, mean lineation $\left(K_{1} / K_{2}\right) ; P$, mean anisotropy degree $\left(P=K_{1} / K_{3}\right) ; T$, Jelinek's parameter $\left[T=\left(\ln \left(K_{2} / K_{3}\right)-\ln \left(K_{1} / K_{2}\right)-\ln \left(K_{2} / K_{3}\right)\right] ; D\right.$, declination; $I$, inclination; $\alpha_{95 \min }\left({ }^{\circ}\right)$ and $\alpha_{95 \max }\left({ }^{\circ}\right)$ : bimodal statistic data [22]. Fabric types: N, 'Normal'; R, 'Reversal'; I, 'Intermediate'; O, 'Other' (see text). 
a) $10-73$
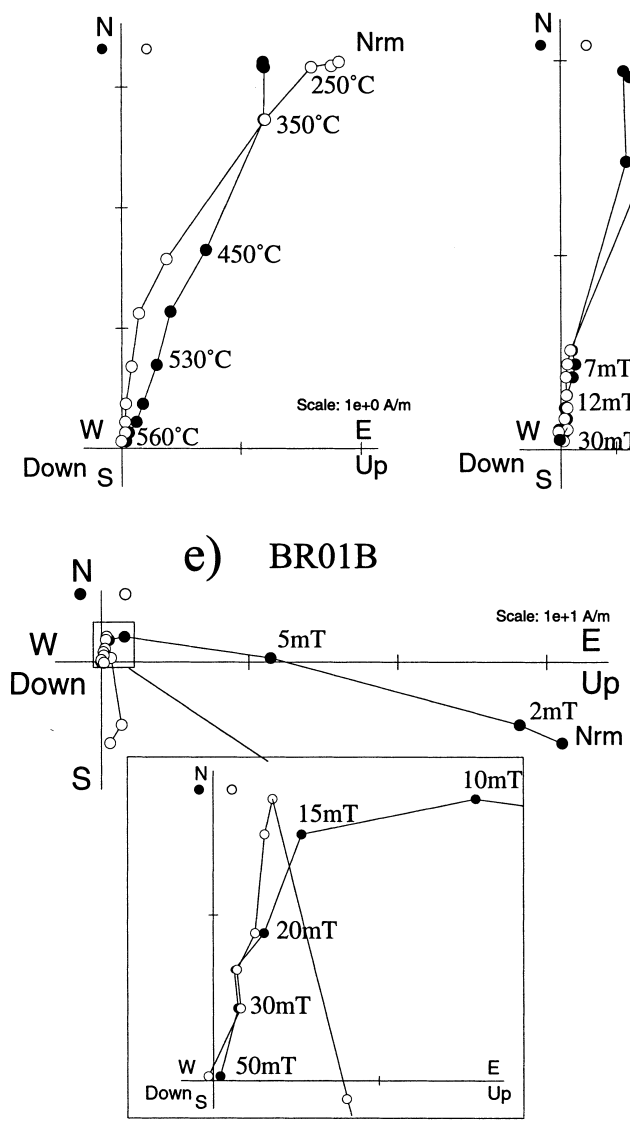

b) $10-72$

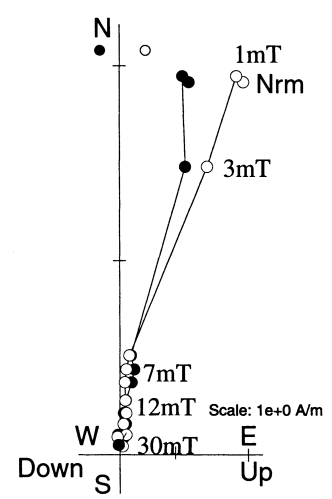

c) GU2A

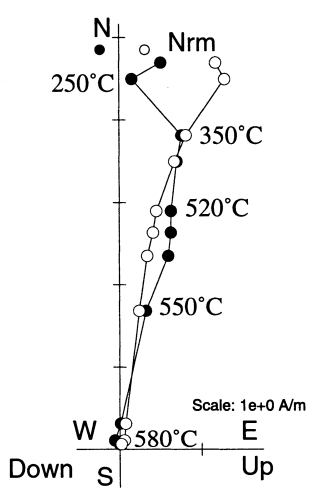

f) $0538 \mathrm{~A}$

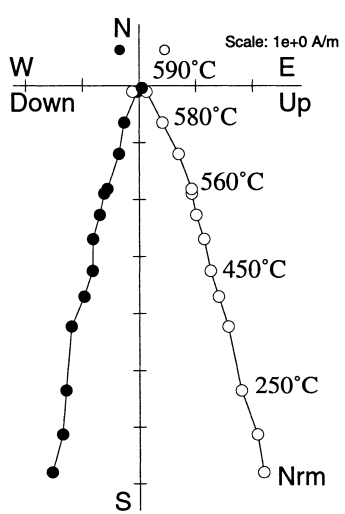

d) $\mathrm{GZ4C}$

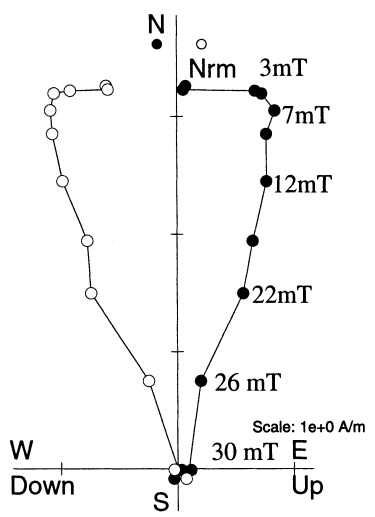

g) GOSD1

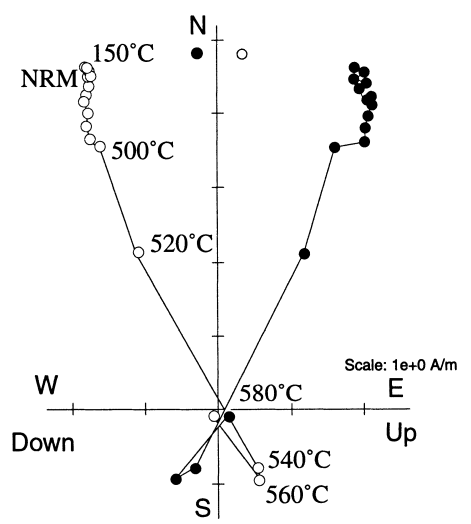

Fig. 5. Representative orthogonal vector diagrams of progressive thermal and AF demagnetization. The closed (open) symbol refer to the horizontal (vertical) plane. (a)-(d) Normal polarity directions, (e) shows a specimen affected by partial lightning, (f) and $(\mathrm{g})$ show reversed directions.

\section{2. $A M S$}

AMS measurements were performed on each specimen using a KLY-3S (AGICO, Geofysica) spinner kappabridge. The AMS results are listed in Table 2 and their tectonic interpretations are discussed in Section 4. The statistic precisions were calculated with bimodal statistics [22] and listed in Table 2. The anisotropy degree $(P)$ is defined by $K_{1} / K_{3}$ where $K_{1}, K_{3}$ are the maximum and minimum susceptibility intensity axes respectively. It is relatively low, varying from 1.009 to 1.082 with an average of 1.03 ( $3 \%$ anisotropy) which is typical order found in dykes [23]. Ellipsoid shape parameter $T$, expressed by $T=$ $(\ln F-\ln L) /(\ln L-\ln F)$ where $F=K_{2} / K_{3}$ and $L=$ $K_{1} / K_{2}$ shows that it is predominantly (25 dykes) oblate $(\mathrm{T}>0)$.

\subsection{Paleomagnetic analyses}

Magnetic remanence was measured on a JR5 spinner magnetometer (AGICO, Geofysica). Natural remanent magnetization (NRM) measurements show a bimodal distribution, ranging from 1 to $10 \mathrm{~A} / \mathrm{m}$ for one group (75\%) and 70$100 \mathrm{~A} / \mathrm{m}$ for other. The group with high intensity values probably suffered an isothermal magnetization due to lightning.

A pilot study was carried out on a few speci- 


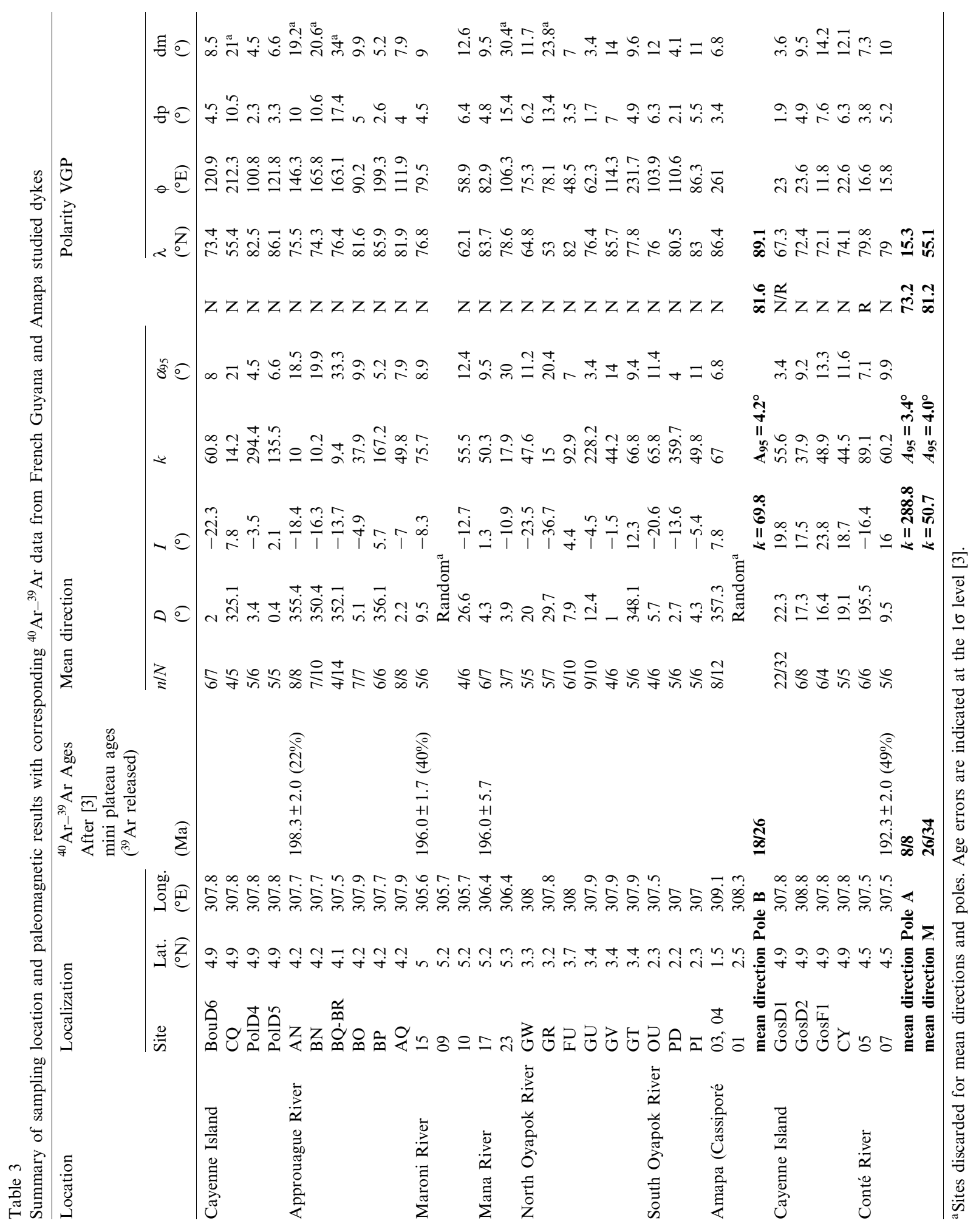


mens using both thermal and alternating field (AF) demagnetization techniques with a Pyrox furnace and an automated three axes tumbler AF demagnetizer (LDA-3, AGICO, Geofysica), respectively. About 12 (AF) to 16 (thermal) demagnetization steps were used. Both techniques provided similar results (Fig. 5a,b) as defined by principal component analysis [24]. After removal of a low coercivity or low unblocking temperature component with random directions, the intensity linearly decays up to maximum applied fields of $30-40 \mathrm{mT}$ or temperatures ranging from 530 to $580^{\circ} \mathrm{C}$ (Fig. 5a-d). For samples possessing high NRM intensities, the AF technique more efficiently isolates the characteristic component after removing the spurious overprint (Fig. 5e). We therefore used AF demagnetization on all other specimens. The magnetic directions are mainly of normal polarity although reversed polarity directions were identified in two sites (Fig. 5f,g). One Site (05) has only reversed polarity directions while the other (GOS D1) a $20 \mathrm{~m}$ wide dyke presents few reversed polarity directions only in the slow cooling coarse grained central part.

The mean direction for each paleomagnetic site, given in Table 3, have been computed by Fisher statistics [25]. They are slightly but systematically different from the present Earth field (declination $=342^{\circ}$, inclination $\left.=18.5^{\circ}\right)$ and the geocentric axial dipole field (inclination $=3-10^{\circ}$ ). The Fisher (k) parameter is usually greater than 10. Directions isolated from the highly magnetized specimens usually led to a poorly defined mean direction with a low $k$ and a large $\alpha_{95}$ (Table 3). The sites which have a low precision parameter value and a $\alpha_{95}$ greater than $15^{\circ}$ (Table 3) were not taken for mean direction and mean virtual geomagnetic pole (VGP) calculations.

\section{Discussion}

\subsection{Implication of AMS results on dyke emplacement}

Based on numerous field observations and AMS studies of characteristics of eigenvector orientations, many authors (e.g. $[10,23])$ suggest that magmatic fabrics in dykes can be classified into four general types: N (Normal), R (Reversal), I (Intermediate) and $\mathrm{O}$ (Other). Type $\mathrm{N}$ is characterized by the clustering of $K_{1}$ and $K_{2}$ axes on the dyke plane, whereas $K_{3}$ is nearly perpendicular to it. Type $\mathrm{I}$ is defined by $K_{1}$ and $K_{3}$ axes clustering close to the dyke plane, whereas $K_{2}$ axis is perpendicular to this plane. Type $\mathrm{R}$ is characterized by $K_{2}$ and $K_{3}$ axes close to the dyke plane and $\mathrm{K}_{1}$ is perpendicular to that plane. AMS axes which do not show any preferential orientation belong to Type O.

In our dykes, the analysis at the individualdyke scale defines four fabrics (Table 2 and Fig. 6): N (21 dykes, 62\%), R (8 dykes, 24\%) I (1 dyke, $2 \%$ ) and $\mathrm{O}$ (4 dykes, $12 \%$ ).

The $K_{1}$ orientation of Type $\mathrm{N}$ (Figs. 6 and 7) is parallel to the NNW-SSE strike of the dykes. The $\mathrm{N}$ fabric type was interpreted as a flow fabric by many researchers (e.g. [23,26,27]) who compared field evidence and AMS data. Moreover, the $K_{1}$ inclination can be used to infer the distance between the fractures and the magma source $[23,28]$. The subhorizontal $K_{1}$ inclinations could correspond to dykes fed horizontally by a distant feeding source. In French Guyana dolerite, all $\mathrm{N}$ fabric $K_{1}$ axes have weak to horizontal inclinations (Figs. 6 and 7), suggesting that French Guyana dolerites are, firstly far from their feeding source ( $>500 \mathrm{~km}$ ) and, secondly fed horizontally from these feeding source and/or magma storage zone. We also notice that the weak $K_{1}$ axes generally dip towards the south (Fig. 7). However, they are almost vertical at one site from Amapa (Site 04; Fig. 6), indicating that this dyke may probably be closer to the magma source with respect to the French Guyana dykes. If the French Guyana and Amapa dykes belong to the same generation and have same magma source, the source could be located to the SE. This conclusion contradicts some workers [29,30], who suggest that the source of the French Guyana dykes was located to the NNW, based on their geographical location and the preferred circum Central Atlantic Ocean dyke orientation.

The reversal fabric was found in eight dykes. It was generally attributed to secondary processes such as hydrothermalism, post-emplacement mod- 


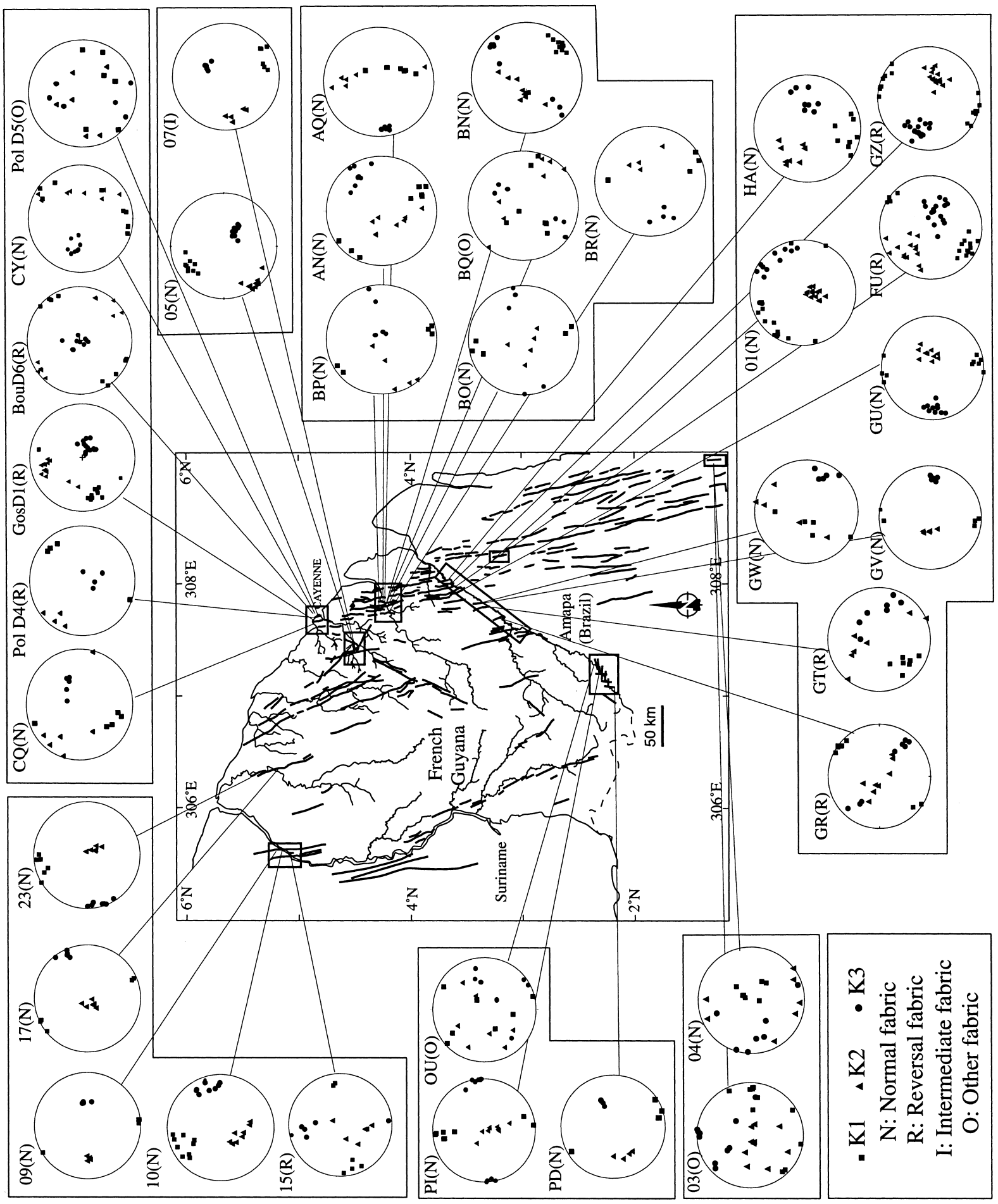

Fig. 6. AMS directions $\left(K_{1}, K_{2}\right.$ and $\left.K_{3}\right)$ from the sampled dolerites of French Guyana. Magmatic fabrics are highlighted as follows: N, 'Normal'; R, 'Reversal'; I, 'Intermediate'; O, 'Other'. 
ification or due to the presence of SD (single domain) grains in rocks [23]. If the analysis in thin sections does not show evidence of hydrothermalism or solid state deformation, shearing deformation has been locally shown by field observations, in contact zone between dykes of Type $\mathrm{R}$ and their host rocks (e.g. GOSD1, BOUD6). We suggest that the $\mathrm{R}$ fabric could be related to local shearing deformation.

The 'Intermediate' fabric (I Type) was recognized in one dyke (Site 07; Fig. 6). Such fabric was found in other swarm [23,31]. It could be explained by the presence of fine-grained (titanomagnetite) [23] or due to the vertical compacting of a static magma column [31]. In this study, petrographic investigation has not permitted to find fine magnetic grain size in this rocks (see Section 3.1 ), so the I fabric may be explained by the compression tending to force the material along the dyke direction during dyke emplacement [31].

\subsection{Implication of paleomagnetic results}

All site-mean directions and poles are listed in Table 3. Due to the large sampling area, all sitemean directions have been transferred to corresponding VGPs before calculating mean poles. The site-mean VGPs are systematically distinct

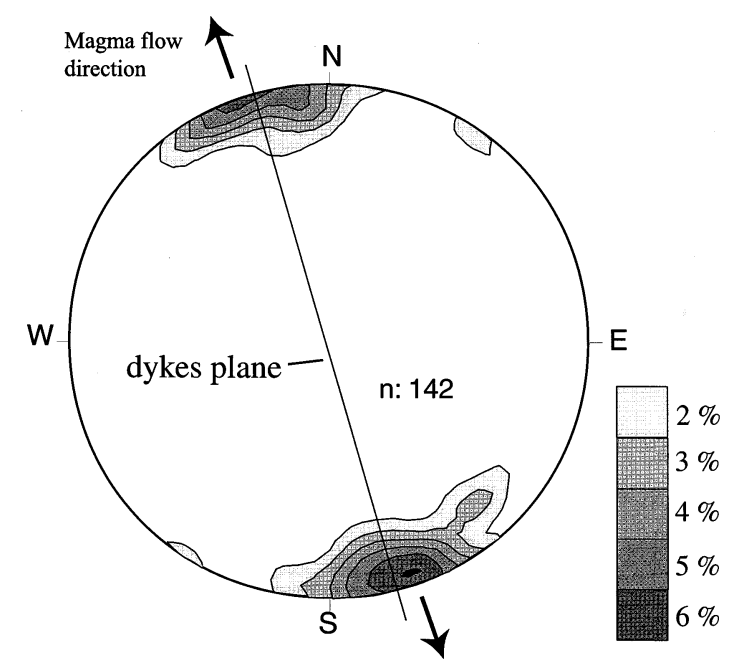

Fig. 7. Density diagram ( $1 \%$ area contours, equal area) of the magnetic lineation ( $K_{1}$ direction) from all samples belonging to the magmatic fabric of Type N. from the present geomagnetic field. Cores collected parallel to the dyke width show consistent directions with generally satisfactory statistic parameters (Table 3). The majority of sites present normal polarities and only two sites show a reversed one (Site 05, GosD1). We also note that the strong weathering which affects this subequatorial area has not yet induced any change in the magnetization of this collection. Indeed, it has been recently shown [32], in the Cayenne area, that independently of the primary magnetic carrier, hematite becomes the main magnetic carrier due to lateritization and no magnetite remains, which is not the case in the present study. Based on the above observations, we can conclude that the magnetic remanence is probably of primary origin representing an Early Jurassic magnetization.

Eight of 34 sampled sites show random or scattered directions due to a partial or to a total overprint attributed to lightning. They were rejected from the mean calculation. From the remaining 26 sites, we calculated an Early Jurassic paleomagnetic pole for French Guyana (Table 3; Fig. 8a; Pole M) with the following coordinates: $\lambda=81.2^{\circ} \mathrm{N}, \phi=55.1^{\circ} \mathrm{E}, k=50.7$ and $A_{95}=4.0^{\circ}$.

A closer look at the VGP distribution shows that two populations could be identified in our data set (Fig. 8a). The disparity between these two populations is predominantly on the polar longitude. Therefore, two sub-mean poles are computed: Pole A: $\lambda=73.2^{\circ} \mathrm{N}, \quad \phi=15.3^{\circ} \mathrm{E}$, $k=288.8, \quad A_{95}=3.4^{\circ}$ and $N=8$; Pole B: $\lambda=81.6^{\circ} \mathrm{N}, \quad \phi=89.1^{\circ} \mathrm{E}, \quad k=69.8, A_{95}=4.2^{\circ}$ and $N=18$. These two poles are statistically distinguished suggesting two distinct magmatic intrusive events (Fig. 8a), although secular variation of the geomagnetic field could also be responsible for part of the data scattering. The only normal polarity evidenced in the majority of dykes may indicate that duration of magmatic intrusion for each group could be very short as reversal rate is relatively high for this Triassic-Jurassic period [33]. Moreover, the two groups do not show the same distribution style, the VGPs from Group B are more dispersed than those from Group A, which may indicate that the intrusion of Group B may have a longer duration. No clear relation- 

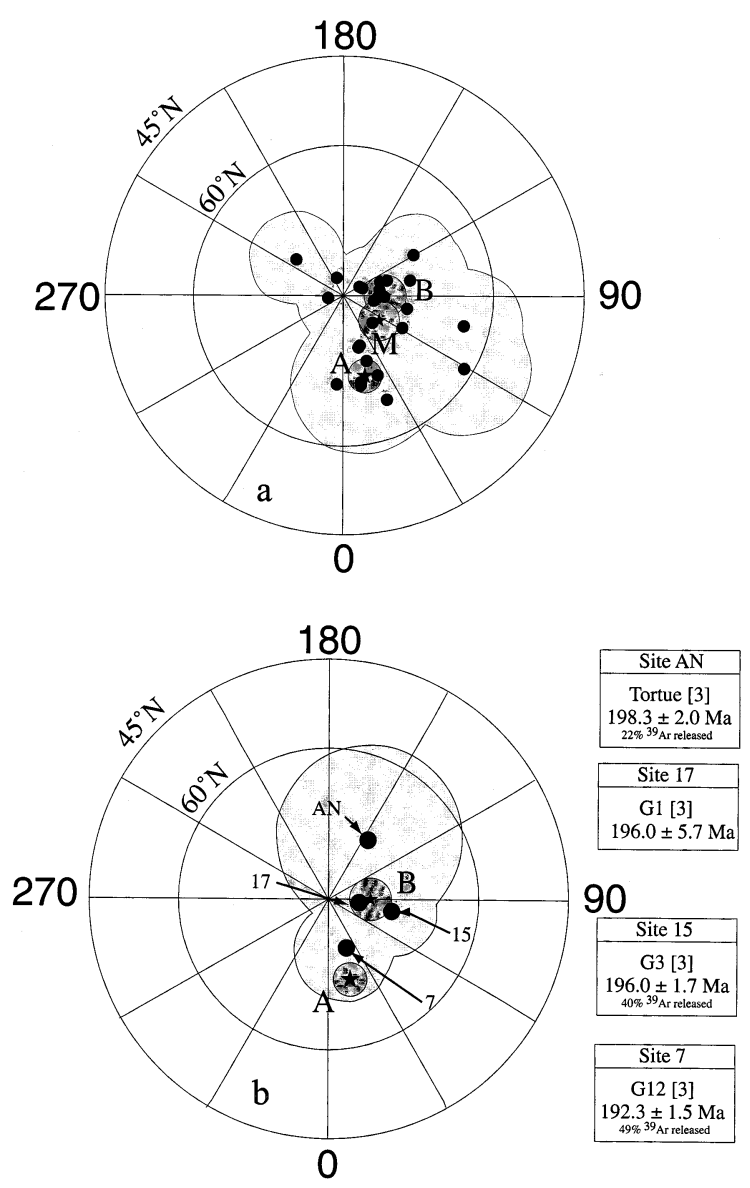

Fig. 8. (a) Equal area projection of the 26 VGP from the French Guyana dolerites with the total mean pole (M) and the proposed pole A and pole B. (b) VGPs from the dated dykes of [3] with our proposed A and B poles. Age errors are given with $1 \sigma$ level.

ship was observed between ASM types and the two VGP groups.

Four of our sampled dykes were recently dated by ${ }^{40} \mathrm{Ar}-{ }^{39} \mathrm{Ar}$ [3]. Sample G1 (Site 17) corresponds to a single grain amphibole age of $196.0 \pm 5.7 \mathrm{Ma}$. According to the authors [3] the large error bars are due to the low $\mathrm{K}$ content and small grain size. The ages obtained from samples Tortue corresponding to the paleomagnetic site: AN, G3 (15), and G12 (7) were determined from plagioclase. All spectra are characterized by variable excess argon and younger K-rich alteration phases. Nevertheless, Deckart et al. [3] indicated that between 770 and $1090^{\circ} \mathrm{C}$ the age spectra dis- play a relatively flat region corresponding to 20 $49 \%$ of total out gassed ${ }^{39} \mathrm{Ar}$ and show three to five concordant successive apparent ages. They also argued that these 'mini-plateau' ages correspond to a minimum contribution of excess argon and/or radiogenic ${ }^{40} \mathrm{Ar}$ from K-rich alteration phases. Furthermore, they presented a bimodal age distribution between 196 and $189 \mathrm{Ma}$ with the 'mini-plateaus' probability diagram of bulk plagioclase of French Guyana dolerites (see figure 6 of [3]). In Fig. 8b, we represent VGPs location sites AN, 15 and 7 and corresponding Tortue, G3, G12 'mini plateau' ages. The two older indistinguishable ages $(198.3 \pm 2.0 \mathrm{Ma}$ and $196.0 \pm 1.7$ Ma) sites $\mathrm{AN}$ and 15 lie on between 150 and $90^{\circ} \mathrm{E}$ longitude. The younger Site $7(192.3 \pm 1.5$ $\mathrm{Ma}$ ) is between 0 and $30^{\circ} \mathrm{E}$.

According to VGP distribution and geochronological data [3], we propose that the two VGP groups could correspond to two distinct magmatic pulses occurring in a short time period. Moreover, all eight sites which define the pole A come from the northeastern part of French Guyana (Cayenne Island, Conté and North Oyapok), while the sites for the pole B cover all sampling area. As proposed by [2] in Brazilian CAMP, the youngest magmatic event seems to be restricted closer to the future rift margin.

\section{Conclusions}

AMS and paleomagnetic studies on recently dated dykes from French Guyana bring new and important insight on the Early Jurassic circum Atlantic volcanic activity which occurred prior to the opening Central Atlantic Ocean. AMS can be segregated into four fabric types according to the eigenvector orientations with respect to the dyke plane. Type $\mathrm{O}$ shows no preferential orientation of the principal axes of anisotropy. The three others $(\mathrm{N}, \mathrm{R}, \mathrm{I})$ present well defined $K_{1}, K_{2}$ and $K_{3}$ directions. Type $\mathrm{N}$ referred as 'Normal' was found in 21 dykes and defined by $K_{1}-K_{2}$ clustering close to the dyke plane and $K_{3}$ is nearly perpendicular to it. This fabric was interpreted as due to the magma flow. Analysis of $K_{1}$ inclination permitted to infer that the dykes of French 
Guyana were fed horizontally from a distant magma source. Type $\mathrm{R}$ ( 8 dykes), is characterized by a $K_{2}-K_{3}$ plane close to the dyke plane and $K_{1}$ perpendicular to dyke orientation. The origin of this magmatic fabric is due to possible local shear stress. Type I, defined by $K_{1}-K_{3}$ axes close to the dyke plane and $\mathrm{K}_{2}$ perpendicular to this plane, was interpreted as due to vertical compaction of the magma column.

The paleomagnetic results from 26 out of 34 sites in French Guyana suggests the existence of two VGP populations and indicates that two short volcanic events took probably place in the French Guyana during the Early Jurassic. The geographical position of the dykes from the two VGP groups indicated a possible migration of the magmatism toward the future rifting zone in French Guyana. To validate these hypotheses, more coupled paleomagnetic and geochronological studies have to be undertaken on similar rocks from the Amazonian Shield and CAMP.

\section{Acknowledgements}

This study was supported by the French geological survey (BRGM) French Guyana mapping project. Drs. C. Delor, D. Lahondere, O. Monod, P. Rossi, M. Vidal, M.T. Lins Faraco and J. M. Carvalho are thanked for their contribution in sampling and discussions. IPGP and Saint Maur laboratories are thanked for offering the possibility to realize preliminary measurements on the Cayenne Island samples. The suggestions proposed by Drs I.G. Pacca, M. Ernesto, J. Glen and an anonymous reviewer are very appreciated for improving the first manuscript. We also thank Dr. G. Féraud and Dr. S. Gilder for their constructive discussion and improvement of the English, R.J. Enkin and J.P. Cogné for the use of their paleomagnetic software.[AC]

\section{References}

[1] A.N. Sial, E.P. Oliveira, A. Choudhuri, Mafic dyke swarms of Brazil, in: H.C. Halls, W.F. Fharig (Eds.),
Mafic Dyke Swarms, Geological Association of Canada Special Paper 34, 1989, pp. 467-481.

[2] A. Marzoli, P.R. Renne, E.M. Piccirillo, M. Ernesto, G. Bellieni, A. De Min, Extensive 200-million-year-old continental flood basalts of the Central Atlantic Magmatic Province, Science 284 (1999) 616-618.

[3] K. Deckart, G. Feraud, H. Bertrand, Age of Jurassic continental tholeiites of French Guyana, Suriname and Guinea: implications for the initial opening of the Central Atlantic Ocean, Earth Planet. Sci. Lett. 150 (1997) 205 220.

[4] M.A. Richards, R.A. Duncan, V.E. Courtillot, Flood basalts and hotspot track plume heads and tails, Science 246 (1989) 103-107.

[5] R.I. Hill, I.H. Campbell, G.F. Davies, R.W. Griffiths, Mantle plumes and continental tectonics, Science 256 (1992) 186-193.

[6] A. Gudmundsson, Mechanical aspects of postglacial volcanism and tectonics of the Reykjanes Peninsula, SouthWest Iceland, J. Geophys. Res. 91 (1986) 12711-12721.

[7] R.I. Tilling, J. Dvorak, Anatomy of basaltic volcano, Nature 363 (1993) 125-132.

[8] D.H Tarling, F. Hrouda, in: D.H Tarling, F. Hrouda, (Eds.), The Magnetic Anisotropy of Rocks, Chapman and Hall, London, 1993, 217 pp.

[9] M. Jackson, L. Tauxe, Anisotropy of magnetic susceptibility and remanence: developments in the characterization of tectonic, sedimentary and igneous fabric, Rev. Geophys. 29 (1991) 371-376.

[10] P. Rochette, L. Jenatton, C. Dupuy, F. Boudier and I. Reuber, Diabase dykes emplacement in Oman ophiolite: A magnetic fabric study with reference to geochemistry, in: T.J. Peters (Ed.), Ophiolite genesis and evolution of oceanic lithosphere, 1992, pp. 55-82.

[11] R.B. Hargraves, Palaeomagnetism of the Roraima dolerites, Geophys. J. R. Astron. Soc. 16 (1968) 147-160.

[12] J. Veldkamp, F.G. Mulder, J.D.A. Zijderveld, Palaeomagnetism of Suriname dolerites, Phys. Earth Planet. Int. 4 (1971) 370-380.

[13] R.B. Hargraves, Problems in palaeomagnetic synthesis illustrated by results from Permo-Triassic dolerites in Guyana, Phys. Earth Planet. Int. 12 (1978) 277-284.

[14] W.D. Macdonald, N.D. Opdyke, Triassic paleomagnetism of the Northern South America, Am. Assoc. Petrol. Geol. Bull. 58 (1974) 208-215.

[15] K. Deckart, Etude du magmatisme associé au rifting de l'Atlantique Central et du Sud: géochronologie ${ }^{40} \mathrm{Ar} /{ }^{39} \mathrm{Ar}$ et géochimie sur les intrusions jurassiques de Guinée et de Guyane française/Suriname, et Cretacées du Brésil, Ph.D. Thesis, Université de Nice-Sophia Antipolis, 1996, 221 pp.

[16] W. Teixieira, C.C.G. Tassinari, U.G. Cordani, K. Kawashita, A review of the geochronology of the Amazonian Craton: tectonic implications, Precambrian Res. 42 (1989) 213-227.

[17] C. Montgomery, P.M. Hurley, Total $\mathrm{U} / \mathrm{Pb}$ and $\mathrm{Rb} / \mathrm{Sr}$ synthetics Imataca serie, Guyana Shield, Venezuela, Earth Planet. Sci. Lett. 39 (1978) 281-290. 
[18] B. Choubert, Le Precambrien des Guyanes, Mem. B.R.G.M. 81, 1974, 213 pp.

[19] E. Manier, D. Mercier, P. Ledru, Sedimentary dynamics of Lower Proterozoic alluvial deposits in French Guyana. Gold mineralization in proximal facies, Spec. Publ. Int. Assoc. Sedimentol. 17 (1993) 553-568.

[20] R.W. Le Maitre, P. Bateman, A. Dudek, J. Keller, M.J. Lameyre Le Bras, P.A. Sabine, R. Schmid, H. Sorensen, A. Strekeisen, A.R. Woolley, B. Zanettin, A Classification of Igneous Rocks and Glossary of Terms, Blackwell, Oxford, 1989.

[21] K.J. Spencer, D.H. Lindsley, A solution model for coexisting iron-titanium oxides, Am. Mineral. 66 (1981) 11891201.

[22] C. Bingham, Distribution on a sphere and on the projective plane, Ph.D. Thesis, University of Yale, New Haven, CT, 1964.

[23] M.I.B. Raposo, Magnetic fabric and its signification in the Florianopolis dykes swarm, southern Brazil, Geophys. J. Int. 131 (1997) 159-170.

[24] J.L. Kirschvink, The least-squares lines and plane and the analysis of paleomagnetic data, Geophys. J. R. Astron. Soc. 62 (1981) 699-718.

[25] R. Fisher, Dispersion on a sphere, Proc. R. Soc. Lond. A 217 (1953) 295-305.

[26] M.D. Knight, G.P.L. Walker, Magma flow directions in dykes of the Koolau complex, Oahu, determined from magnetic fabric studies, J. Geophys. Res. 93 (1988) 4301-4319.
[27] B.B. Elwood, Flow and emplacement direction determined for selected basaltic bodies using magnetic susceptibility anisotropy measurements, Earth Planet. Sci. Lett. 41 (1978) 254-264.

[28] R.E. Ernst, W.R.A. Beragar, Evidence from magnetic fabric for the flow pattern of magma in the Mackenzie giant radiating dyke swarm, Nature 356 (1992) 511513.

[29] M. Wilson, Thermal evolution of the Central Atlantic margins: continental break-up above a Mezosoic superplume, J. Geol. Soc. Lond. 154 (1997) 491-495.

[30] R.E. Ernst, K.L. Buchan and H.C Palmer, Giant dyke swarms: Characteristics, distribution and geotectonic applications, in: G. Baer, A. Heimann (Eds.), Physics and Chemistry of Dykes, 1995, pp. 3-21.

[31] K. Park, E.I. Tanczyk, A. Desbarats, Magnetic fabric and its significance in the 1400 Ma Mearly diabase dykes of Labrador, Canada, J. Geophys. Res. 93 (1988) 13689 13704.

[32] H. Théveniaut, P. Freyssinet, Paleomagnetism applied to lateritic profiles to assess saprolite and duricrust formation processes: the example of the Mont Baduel profile (French Guiana), Palaeogeogr. Palaeoclimatol. Palaeoecol. 148 (1999) 209-231.

[33] F.M. Gradstein, F.P. Agtergerg, J.G. Ogg, J. Van Veen, P. Thierry, Z. Huang, A Triassic, Jurassic and Cretaceous timescale, in: W.A. Berggren, D.V. Kent, M.P. Aubry, J. Hardenbol (Eds.), Geochronology, Time Scales, SEPM special publication 54, 1995. 